\title{
CLOSE PERSONAL RELATIONSHIPS AT WORK AND WITH KIN: TESTING AN URBAN SUBCULTURE THEORY MODEL
}

Gretchen J. Hill

University of Kansas

Mid-American Review of Sociology, 1987, Vol. XII, No. 2:51-70

Urban subculture theory asserts that living in urban areas provides opportunities for the establishment of social worlds based more on personal interest than on either kinship or traditional affiliations, resulting in urbanites' reduced involvement with kin through selective integration of family into social networks. Based on this theory, and findings supporting it, a model predicting strength of kinship ties was constructed to test its usefulness in predicting the inclusion of kin among individuals' closest personal relationships. At the same time, the model was used to look at the relationship between kinship ties and ties to co-workers, and to test whether there is a work friendship - kinship tie trade-off. Attention was given to differences between age-groups, and to whether kinship ties and co-worker friendships, including any trade-off between the two types of relationships, vary by age, as an indicator of life cycle stage. Regional differences in the application of the model were also considered. Results using a nation-wide sample of workers in the United States suggested that, contrary to urban subculture theory, closeness to kin tends to increase as residence becomes more urban. However, in separate regional and age-group analyses the model did appear to have some application as a preditctor of close kinship ties and ties with co-workers, and the workplace did appear to serve as a source of friendships which of fset the importance of kinship ties for some age-groups cross-regionally, and across age-groups in some regions of the country. Overall, results suggested that the factors predicting close ties with kin differ for different age-groups, and vary across different regions of the country.

Among the theories addressing the effects of urbanism on social life, Claude S. Fischer's $(1982,1983)$ urban subculture theory maintains that the population critical mass of urban areas provides opportunities for the establishment of social worlds based more on 
Mid-American Review of Sociology

pinship or traditional affiliations, personal interest than th urban such as neighborhood and church. Acregard" kin subculture theory, urban life encourages people to "disregard support. Those urbanites maintaining active ties with kin do so on a somewhat more voluntary basis than do residents of less urban However, this lack of active involvement with kin does not areas. How merely indicates inactivated or mean mach reactivated in times of crisis. Thus, dormalture theory views urbanites' reduced involvement with kin as subculture the integration of family into individuals' sor disintegration proposed by breakdown theorists. subculture theory's propositions regarding kinship ties and a provide the main focus of this paper. Based on Fischer's work, a model predicting strength of kinship ies will be tested using data from a nation-wide sample. Attention will be given to differences between age-groups, and regional will be given to diffences will be explored.

The propositions of Fischer's (1982) urban subculture theory are based upon findings of his 1979 northern California study of urban-nonurban differences in social networks. In that study, urban-nonures, on the average, in their social urbanites named fewer relatives, on the also, urbanites' networks networks than did nonurban resity included fewer relatives for social interaction; in and thus presumably available for social interaction, in comparison, small town and semirural respondents named However, the of their available kin in their social networks. Has difference between urban and nonurban respondents answers was narrower for two specific questions: (1) "Whose opinion do you consider seriously in making important decisions?" and, (2) "Who could you ask to-lend you money?" Considering these findings in counces (e.g., "What about in an ene you could probably emergency situation--is there ancl Fischer concluded that urban residents rely on kin almost as much as their nonurban counterparts in times of need, a mode of reliance on kin which has been indicated by other researchers (Litwak and Szelenyi, 1969; Shulman, 1976; Wellman, 1981). Fischer's other findings suggested that, in addition to nonurban other findings suggested living, social involvement with kin is more common for women, those who are married, parents, middle-aged

male), and those living near many relatives.

While maintaining that urbanites' kinship dormant, Fischer did express concern as to whether long dormant
Close Relationships: Work and Family

kinship ties could be reactivated when necessary. It would seem that a maintained sense of closeness with kin despite lack of frequent interaction would facilitate reactivation of long dormant ties (Litwak and Szelnyi, 1969; Roberto and Scott, 1986; Solano, 1986). Although Fischer found that, on average, urbanites named fewer "close" kin than did nonurban respondents, he asked about only those persons whom respondents had previously named in response to questions about their interactions and social contacts. Focusing on relationships characterized by social interaction and contact as indicators of an individual's subjective sense of connectedness to others does not tap those close ties wherein the parties sustain feelings of closeness sans frequent interactions (Derlega and Winstead, 1986). People of ten maintain a sense of closeness with others from whom they are separated by vast distances and with whom they have little contact. It has also been indicated that this closeness provides a sense of potential social support (Lee and Cassidy, 1985; Matthews, 1986). For these reasons, it would be worthwhile to find out whether Fischer's model for predicting extent of kinship integration into social networks is useful for predicting the occurrence of close kinship ties among individuals' closest relationships.

With respect to individuals' ties with nonkin, urban subculture theory maintains that non-traditional social contacts (that is, contacts through sources other than family, neighborhood, and church) provide urbanites with avenues for developing nonkin friendships. One such alternative source for making contacts which develop into friendships is the workplace. However, urban subculture theory makes contradictory predictions regarding urbanites' involvement with co-workers. On one hand, the large specialized workplaces usually located in cities provide opportunities to form relations based upon common work interests, relations which are subsequentiy expanded to other interests. Thus, urbanites should exhibit greater social involvement with coworkers in comparison to residents of less urban areas. On the other hand, the workplace is similar to neighborhood and kin in that it provides a pre-determined set of potential associates. Where alternative sources of relationships are scarce (such as in the small community), individuals will tend to rely on such a pool. Where alternatives are easier to find (such as in urban areas), individuals will more of ten look beyond the workplace to find friends with similar interests. Therefore, urbanites should exhibit less social involvement with co-workers in comparison to residents of less urban areas. Fischer (1982) found no clear relationship between urbanism and co-worker involvement. Additionally, the effects of 
respondents' personal characteristics on co-worker involvement were minimal, ${ }^{1}$ and although co-worker involvement has been found to vary by occupation or industry (Bulmer, 1975; Lipset, et al., 1956; Pilcher, 1972), such differences were negligible in Fischer's study.

The first premise, that co-workers provide a non-traditional source for establishing social relations based on interest, and that urbanites disregard kin by establishing such relations, suggests a kinship tie - nonkin tie trade-off. That is, urbanites' involvement with co-worker friends would be high while their kinship ties would be low; nonurban residents' kinship ties would be high compared to ties with co-workers. On the other hand, the theory also maintains that, unlike their nonurban counterparts, urbanites are not limited to either family or workplace for establishing relationships. Therefore, it would be predicted that urbanites' kinship ties and their social involvement with co-workers both would be low compared to their nonurban counterparts. An application of Fischer's model modified to include work friendship variables could be used to look at the relationship between kinship ties and ties to co-workers, and to test whether a work friendshipkinship tie trade-off exists.

Beyond the effects of urban and nonurban environments, an individual's stage in the life cycle is likely to have an effect on the maintenance of both kin and nonkin ties (Atchley, 1972; Derlega and Winstead, 1986; Lee and Cassidy, 1985; Matthews, 1986; Milardo, 1986; Fehr and Perlman, 1985; Powers and Bultena, 1976; Roberto and Scott, 1986; Rosow, 1967). Differences in time, energy, competing commitments, and disposable income available to people of different stages of the life cycle, as well as the reduction with age in friends who can serve as introducers to potential nonkin friends, all affect individuals' involvement with kin (Fischer, 1982): Most studies inciicate that older-individuals tend to be more involved with kin, especially extended kin, than are younger respondents. However, a majority of the respondents in these studies are retired persons. The effects of older persons' workplace involvement on their kin and nonkin ties has received little attention. Employed middle-aged individuals vary in extent of involvement with both kin and co-workers. While they are more likely to have a spouse and children with which to be involved, they also tend to be at career stages where time spent with coworkers is high. Consequently, it is likely that extent of both kinship ties and co-worker friendships, including any trade-off between the two types of relationships, vary by age, as an indicator of life cycle stage. Thus, age would be an important predictor of the composition of an individual's social world.

\section{METHODS}

Data Source.

Fischer maintains that his northern California sample may adequately represent urban-nonurban differences cross-regionally in the United States. However, he is among those calling for nation-wide studies in the effects of urbanization on kinship and on social networks (Christenson, 1983; Fischer, 1982; Kivett, 1985; Lee and Cassidy, 1985). Keeping in mind the possibility that regional differences in urban-nonurban distinctions threaten to cancel each other out, a nation-wide data set was selected for a test of an urban subculture theory model.

The data source is a comparative project on class structure and class consciousness ${ }^{2}$ designed for the study of class relations and class structures and their effects. The survey contains a fairly broad range of questions, including conventional sociological questions on occupation, industry, geographical location, sex, race and ethnicity. The sample for the national study was drawn through a systematic cluster sample of telephone numbers in coterminus United States. The universe consists of adults, 18 years and older in the United State who are either (a) working, (b) not working but wanting to work, or (c) housewives with working spouses. The data was collected through telephone interviews. The sub-sample drawn for the present study includes only those respondents over the age of 20 . The first test of the model will be made on a sample including workers and nonworkers. All subsequent models will use sub-samples consisting of only those who were working at the time of their interview, excluding housewives and the unemployed... Because the effects of age on kinship ties has been found to occur primarily for the middle-aged and older (Fischer, 1982), a truncated sample of middle-aged and older workers also will be used for further analysis.

Characteristics of Sub-sample.

The characteristics of the sub-sample of working respondents age 21 and over are summarized in Table 1 . All respondents are working at least part time (the majority working 40 hours or more), and ages range from 21 to 90 , with an average age of 36.6 years. Respondents are predominantly white nonhispanic $(90 \%)$. The majority of respondents are married, average level of education is 13.4 years, and both the average and the median annual household 
TABLE 1. CHARACTERISTICS OF SAMPLE BY AGEGROUPS ${ }^{a}$

\begin{tabular}{|c|c|c|c|c|c|c|}
\hline & $21-30$ & $31-40$ & $41-50$ & $51-60$ & OVER 60 & ALL AGES \\
\hline FEMALE & 42.5 & 42.3 & 46.7 & 45.8 & 54.9 & 44.5 \\
\hline $\begin{array}{l}\text { MARITAL STATUS } \\
\text { MARRIED } \\
\text { WIDOWED } \\
\text { DIVORCED } \\
\text { NEVER MARRIED }\end{array}$ & $\begin{array}{r}56.0 \\
.2 \\
7.0 \\
36.9\end{array}$ & $\begin{array}{r}70.0 \\
1.7 \\
16.5 \\
11.8\end{array}$ & $\begin{array}{r}70.7 \\
2.3 \\
17.7 \\
9.3\end{array}$ & $\begin{array}{r}70.7 \\
8.7 \\
14.4 \\
6.3\end{array}$ & $\begin{array}{r}64.0 \\
17.4 \\
9.3 \\
9.3\end{array}$ & $\begin{array}{c}65.1 \\
3.4 \\
12.7 \\
18.8\end{array}$ \\
\hline PARENTS & 36.6 & 73.1 & 73.8 & 61.1 & 42.9 & 57.1 \\
\hline $\begin{array}{l}\text { LEVEL OF EDUCATION } \\
0 \text { TO } 8 \text { YRS } \\
9 \text { TO } 11 \text { YRS } \\
12 \text { YEARS } \\
13 \text { TO } 15 \text { YRS } \\
\text { OVER } 16 \text { YRS }\end{array}$ & $\begin{array}{r}.5 \\
5.7 \\
30.5 \\
30.1 \\
33.3\end{array}$ & $\begin{array}{r}3.4 \\
4.9 \\
30.2 \\
29.0 \\
32.5\end{array}$ & $\begin{array}{r}7.2 \\
14.8 \\
29.7 \\
21.5 \\
26.8\end{array}$ & $\begin{array}{r}5.8 \\
17.8 \\
33.0 \\
17.3 \\
26.2\end{array}$ & $\begin{array}{l}17.7 \\
19.0 \\
30.4 \\
19.0 \\
13.9\end{array}$ & $\begin{array}{c}4.3 \\
9.6 \\
30.6 \\
25.8 \\
29.7\end{array}$ \\
\hline $\begin{array}{l}\text { ANNUAL HOUSEHOLD } \\
\$ 0 \text { TO } \$ 10,000 \\
\$ 10,000 \text { TO } \$ 25,000 \\
\$ 25,000 \text { TO } \$ 40,000 \\
\text { OVER } \$ 40,000\end{array}$ & $\begin{array}{l}\text { VCOME } \\
19.8 \\
53.1 \\
19.8 \\
7.3\end{array}$ & $\begin{array}{r}8.3 \\
43.9 \\
35.0 \\
12.7\end{array}$ & $\begin{array}{l}13.0 \\
35.8 \\
33.7 \\
17.6\end{array}$ & $\begin{array}{r}9.8 \\
42.1 \\
30.5 \\
17.7\end{array}$ & $\begin{array}{r}14.6 \\
47.1 \\
14.7 \\
8.8\end{array}$ & $\begin{array}{l}14.4 \\
45.7 \\
27.5 \\
12.1\end{array}$ \\
\hline $\begin{array}{l}\text { OCCUPATION } \\
\text { LABORER } \\
\text { SERVICE } \\
\text { MANAGERS } \\
\text { PROFFESSIONAL }\end{array}$ & $\begin{array}{r}36.8 \\
33.3 \\
20.7 \\
9.2\end{array}$ & $\begin{array}{l}30.9 \\
26.9 \\
30.9 \\
11.2\end{array}$ & $\begin{array}{r}32.1 \\
32.4 \\
28.4 \\
7.1\end{array}$ & $\begin{array}{r}35.8 \\
31.2 \\
25.1 \\
7.9\end{array}$ & $\begin{array}{r}41.8 \\
38.8 \\
20.9 \\
6.6\end{array}$ & $\begin{array}{c}34.6 \\
30.9 \\
25.5 \\
9.0\end{array}$ \\
\hline $\begin{array}{l}\text { WORK WEEK } \\
3 \text { TO } 20 \text { HOURS } \\
21 \text { TO } 39 \text { HOURS } \\
40 \text { HOURS } \\
41 \text { TO } 60 \text { HOURS } \\
\text { OVER } 60 \text { HOURS }\end{array}$ & $\begin{array}{r}3.6 \\
16.0 \\
37.4 \\
37.9 \\
5.1\end{array}$ & $\begin{array}{r}6.3 \\
14.2 \\
27.8 \\
45.7 \\
6.0\end{array}$ & $\begin{array}{r}2.0 \\
15.7 \\
38.6 \\
36.5 \\
7.1\end{array}$ & $\begin{array}{r}3.6 \\
16.9 \\
38.5 \\
34.4 \\
6.7\end{array}$ & $\begin{array}{r}12.0 \\
21.7 \\
34.9 \\
25.3 \\
6.0\end{array}$ & $\begin{array}{c}5.4 \\
15.3 \\
35.0 \\
38.3 \\
6.0\end{array}$ \\
\hline $\begin{array}{l}\text { URBANISM OF RESIDE } \\
\text { RËRAL } \\
\text { SEMIRURAL } \\
\text { TOWN } \\
\text { METRO } \\
\text { CORE }\end{array}$ & $\begin{array}{l}\text { CE } \\
10.7 \\
21.0 \\
17.7 \\
26.7 \\
23.9\end{array}$ & $\begin{array}{l}10.2 \\
21.0 \\
21.3 \\
23.7 \\
23.7\end{array}$ & $\begin{array}{l}12.5 \\
22.5 \\
51.7 \\
40.0 \\
41.6\end{array}$ & $\begin{array}{r}6.2 \\
22.5 \\
36.8 \\
45.8 \\
44.9\end{array}$ & $\begin{array}{l}17.6 \\
25.0 \\
11.5 \\
14.2 \\
13.5\end{array}$ & $\begin{array}{l}10.6 \\
21.7 \\
19.4 \\
26.0 \\
22.4\end{array}$ \\
\hline TOTAL & 33.6 & 27.5 & 16.5 & 15.8 & 6.7 & 100.0 \\
\hline
\end{tabular}

aColumn percentages income is in the range of $\$ 20,000$ to $\$ 25,000$. About one-third of the respondents are laborers, approximately one-third work in the service sector, and approximately one-third are managers and professionals.

\section{Kinship ties.}

The dependent variable used in analysis was derived from answers to the following question set:

Think of the three people to whom you feel personally closest aside from your parents or spouse.

Think of the first of these three people. Is this person a friend or relative?...Now think of the second of these three people. Is this person a friend or a relative?...Now think of the third of these three people. Is this person a friend or a relative?..

Information from the responses to this set of questions was used to construct an index of the proportion of a respondent's closest relationships that are also kinship ties ("kinties"). Despite the exclusion of parents and spouses among possible close relationships, this measure may indicate stronger kinties than Fischer (1982) found by asking the question, "Who are the people you think of as your closest friends?" Fischer found that his question yielded an average of four network members per respondent, a network comprised of only 14\% kin (1982:294). Fischer's use of the word "friends" may have provided a bias in favor of nonkin ties, since most people make a strict distinction between "kin" and "friend" (Derlega and Winstead, 1986).

\section{Co-worker friendships.}

The--variable used as an indicator of co-worker friendships ("work-friends") was obtained using the following question:

We would like to know something about your friendships at work. Which of the following best describes your situation: (1) I have close friends at work, or (2) I have friends at work, but I would not consider them close friends, or (3) I only have acquaintances at work.

Urbanism.

Fischer's (1982) urbanism scale was used to classifiy the urbanness of respondents' residential communities. Using respondents' zip codes (the only available information regarding 
area of respondents' residences), residential locations were determined and classified using information for Standard Metropolitan Statistical Areas (SMSAs) provided by the United States Bureau of the Census (1970). The urbanism scale ranged from 1 (rural and population less than 2,000) to 9 (core city, SMSA population over 900,000$)$.

Regions.

Because studies have indicated that regional differences can mask the effects of urbanism (Abrahamson and Carter, 1986), the sample was divided into four regions based on the U.S. Census Bureau categorization. ${ }^{3}$ The Pacific/Mountain region consists of the following states: Washington, Oregon, California, Idaho, Utah, and Colorado. The North Central region includes: South Dakota, Nebraska, Kansas, Montana, Missouri, Iowa, Wisconsin, Illinois, Michigan, Indiana, Ohio. The South region includes: Kentucky, Tennessee, Mississippi, Alabama, Florida, Georgia, South Carolina, North Carolina, Virginia, West Virginia, Maryland, and the District of Columbia. Finally, New York, New Jersey, Pennsylvania, Connecticut, Rhode Island, Maine, Vermont, New Hampshire, and Massachusetts comprise the East Coast region.

\section{Data Analyses.}

Multiple regression analysis was performed for proportion of kin among respondent's close relationships (kinties) using the following independent variables suggested by urban subculture theory: respondent's age, sex, marital status, annual household income, parental status, the extent to which co-workers also lived in respondent's neighborhood, and urbanism of respondent's residential community. This analysis was first performed for the sub-sample of working and nonworking respondents ages 21 and older, then for working respondents ages 21 and older, and finally for the truncated sample of middle-aged and older respondents, ages 41 and older.

Separate multiple regression analyses were conducted for the following age-groups: 21 to 30 years; 31 to 40 years; 41 to 50 years; 51 to 60 years; and 61 years and older. In these seperate analyses, the variables tested as predictors were the same as those in the analysis of the entire sample; kinties were again the dependent measure.

Separate multiple regression analyses were conducted for the following regions: Pacific/Mountain, North Central, South, and East Coast. In these tests, the variables used as predictors were the same as those in the analysis of the entire sample and kinties were again the dependent measure. Then, regional analyses were conducted using the truncated sample of middle-aged and older respondents.

With the exception of the urbanism variable, the workers' model was used to conduct separate multiple regression analyses for the following community types: rural, semi-rural, small town, metro (suburban SMSAs), and urban core. Then, separate community analyses were conducted using the truncated sample of middle-aged and older respondents.

\section{RESULTS}

Urbanism and Workfriend-Kintie Trade-off.

Results of regression analyses for the sample as a whole are presented in Table 2. The first model indicates that ubanism is not a good predictor of kin ties. Although being a parent did not increase the likelihood of having strong kinties, being female, being married, and having lower income, were all related to close kinties. In addition, as age increased, so did strength of kinship ties. The second model indicates that, in opposition to Fischer's findings, stronger kinties occurred with increasing residential urbanism. Otherwise, although the amount of variance explained by the urban subculture theory model was small, it did fit fairly well for the overall sample. Age was a significant predictor of kinties: older respondents were more likely to report close kinties. Also, there did appear to be an of fset between work-friends and kinties: the closer the respondent was to work-friends, the weaker were his or her kinties (and vice versa).

Results of regression analyses for the truncated sample of workers age 41 and older also are presented in Table 2 as model 3. Here, the urban subculture model did not work well. However, the of fet between work-friends and kinties was much more evident for these middle-aged and older workers. Age continued to be a significant predictor of kinties. Additionally, having less education and living near co-workers both were related to close kinties.

\section{Age differences.}

Results of regression analyses for the five age-groups are presented in Table 3 . These results indicated that the urban subculture model is not a usful predictor of kinties for separate age-groups. Also, the trade-of $f$ between close work-friends and strong kinties was not found for all ages, as it only occurred for the 31-to-40 and 41-to-50 age-groups, most notably for the latter. 
Mid-American Review of Sociology

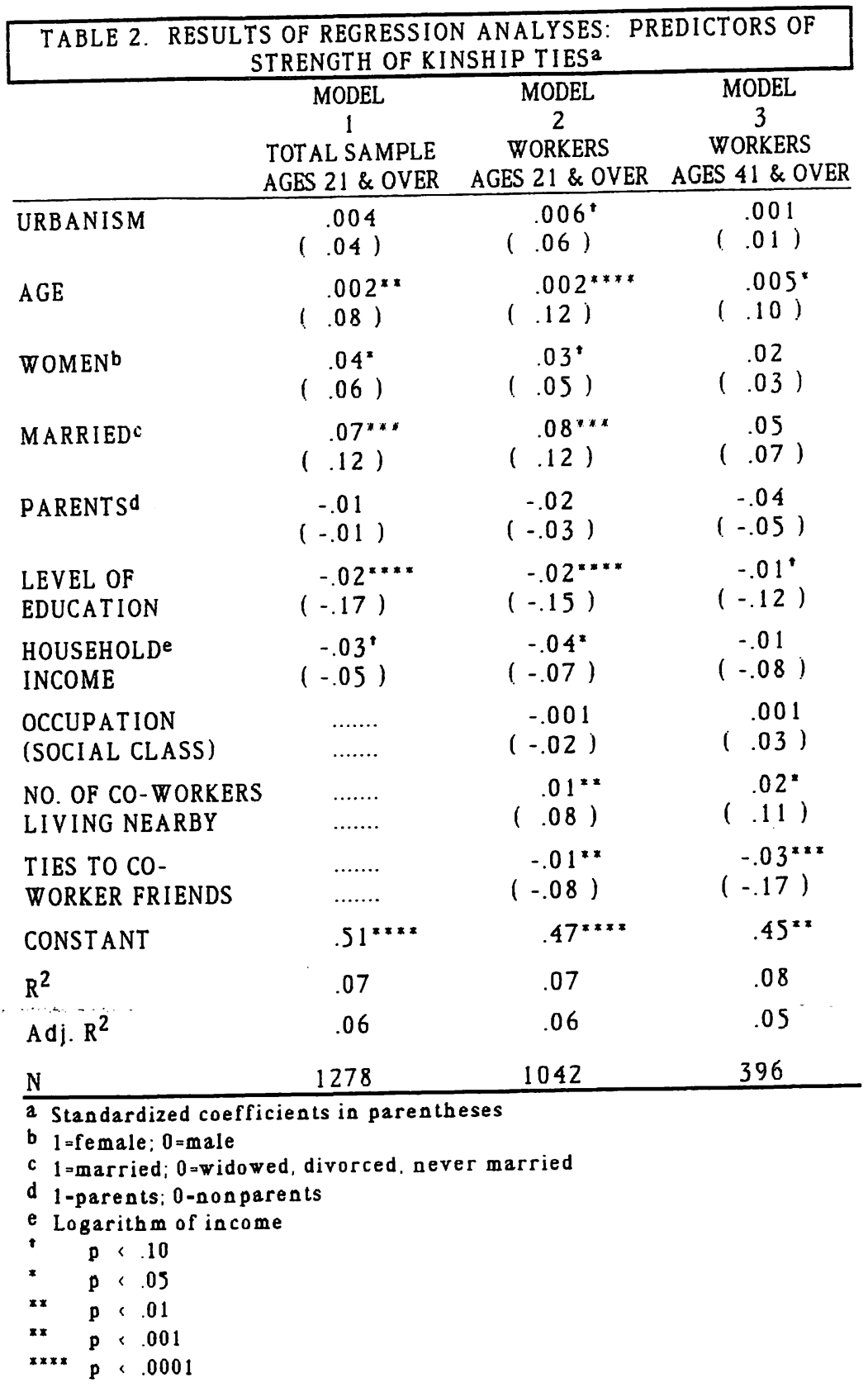

Close Relationships: Work and Family

TABLE 3. RESULTS OF REGRESSION ANALYSES:

PREDICTORS OF STRENGTH OF KINSHIP TIES AMONG ADULT WORKERS BY AGEa

MODEL MODEL MODEL MODEL MODEL

\begin{tabular}{|c|c|c|c|c|c|}
\hline & $\begin{array}{c}1 \\
21-30 \\
\end{array}$ & $\begin{array}{c}2 \\
2 \\
31-40 \\
\end{array}$ & $\begin{array}{c}3 \\
41-50 \\
\end{array}$ & $\begin{array}{c}4 \\
51-60 \\
\end{array}$ & $\begin{array}{c}5 \\
5 \\
\text { OVER } 60 \\
\end{array}$ \\
\hline URBANISM & $.008^{\circ}$ & .006 & .0002 & .006 & .01 \\
\hline
\end{tabular}

$\begin{array}{lllll}(.09) & (.06)(.0026)(.05) & (.02)\end{array}$

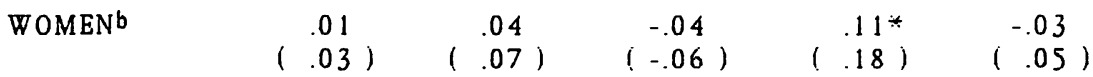

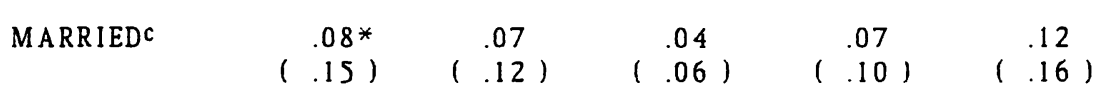

PARENTSd $^{d}\left(\begin{array}{lllll}.03 & -.03 & -.04 & -.01 & -.15\end{array}\right.$

$\left(\begin{array}{lllll}(.05) & (-.05)(-.05)(-.02) & (-.20)\end{array}\right.$

LEVEL OF $\quad-.02^{* *} \quad-.01^{*} \quad-.01 \quad-.01 \quad-.004$

EDUCATION $(-.16)(-.15)(-.13)(-.08)(-.04)$

$\begin{array}{llllll}\text { HOUSEHOLD } & -.006 & -.003 & -.02^{\circ} & .006 & -.02 \\ \text { INCOME } & (-.05) & (-.02) & (-.16) & (.04) & (-.15)\end{array}$

$\begin{array}{llllll}\text { OCCUPATION } & .001 & -.004 & .003 & -.002 & -.007\end{array}$

(SOCIAL CLASS) $(.04) \quad(-.11) \quad(.08) \quad(-.04) \quad(-.12)$

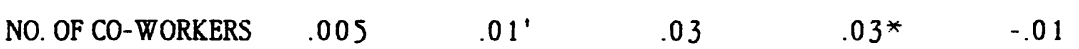

LIVING NEARBY $(.03)(.09) \quad(.09) \quad(.19) \quad(-.06)$

$\begin{array}{llllll}\text { TIES TO CO- } & .004 & -.01^{\prime} & -.04^{* * * *} & -.007 & -.03\end{array}$

WORKER FRIENDS $(.03)(-.09)(-.26)(-.04)(-.16)$

CONSTANT $\quad .49 * * * * \quad .58 * * * * \quad .82^{* * * *} \quad .46 * * \quad .77 * *$

$\begin{array}{llllll}\mathrm{R}^{2} & .06 & .08 & .12 & .08 & .17\end{array}$

$\begin{array}{llllll}\text { Adj. } R^{2} & .04 & .05 & .07 & .02 & .001\end{array}$

$\begin{array}{llllll}\mathrm{N} & 376 & 294 & 182 & 154 & 60\end{array}$

a Standardized coefficients in parentheses

b 1 - female: $0=$ male

c l=married: $0=$ widowed, divorced, never married

d 1 =parents; 0 =nonparents

e Logarithm of income

$+p<.10$

* $\quad p<.05$

** $\quad \mathrm{p}<.001$ 
In summary, close kinties were more likely for respondents in urban areas, older respondents, women, the married, the lesseducated, those with lower incomes, those living near co-workers, and those without close work-friends. For middle-aged and older workers, close kinties were more likely for older respondents, the less-educated, those living near co-workers, and those without close work-friends. For the 21 to 30 year old urban residents, the married, and the less-educated tended to have close kinties. The less-educated, those living near co-workers, and those without close work-friends had closer kinties among those ages 31 to 40 . Those with low household incomes and those without close work-friends wre more likely to have close kinties among the 41 to 50 age-group. For the ages 51-to-60 respondents, close kinties were more likely for women and those living near co-workers. Finally, this prediction model did not fit the over-60 age-group.

\section{Regional differences.}

Results of regression analyses for the four regions are presented in Table 4. The urban subculture model did not appear to apply well to any of the regions. For the South, which was the only region for which the trade-off between work-friend and kinties was evident, more of the variance was explained by the model than for the other regions. Urbanism was not a significant predictor of kinties for any region by itself. Age was a significant predictor for all regions except the South.

Results of regression analyses for the four regions using the truncated sample of middle-aged and older workers are presented in Table 5. When considering only middle-aged and older workers, the of fset of close kinship ties with close co-worker friendships was found for all four regions. However, age was not a significant predictor in any of the regions, a possible result of truncating the sample by age. Interestingly, when limiting the analysis to middleaged and older workers, results for the Pacific/Mountain region (which includes the area where Fischer's study was conducted) provided some support for the urban subculture theory. That is, urbanism was a significant predictor of extent of kinties, and in the direction held by the theory: the less urban the respondent's residence the more likely (s)he was to have close kinties. Also of interest, sex was related to kinties for both the North Central region and the South, but men tended to have closer kinties in the former while women had closer kinties in the latter. Living near co-workers was related to kinties for North Central, South, and East Coast regions. However, living near co-workers predicted
TABLE 4. RESULTS OF REGRESSION ANALYSES: PREDICTORS OF STRENGTH OF KINSHIP TIES AMONG WORKERS AGES 21 \& OVER BY REGIONa

\begin{tabular}{|c|c|c|c|c|}
\hline & $\begin{array}{c}\text { MODEL } \\
1 \\
\text { PACIFIC/MTN } \\
\end{array}$ & $\begin{array}{c}\text { MODEL } \\
2 \\
\text { NO. CENTRAL } \\
\end{array}$ & $\begin{array}{c}\text { MODEL } \\
3 \\
\text { SOUTH } \\
\end{array}$ & $\begin{array}{c}\text { MODEL } \\
4 \\
\text { EAST COAST } \\
\end{array}$ \\
\hline URBANISM & $\begin{array}{l}-.002 \\
(-.01)\end{array}$ & $\begin{array}{l}.008 \\
(.08)\end{array}$ & $\begin{array}{r}-.004 \\
(-.03)\end{array}$ & $\begin{array}{l}.009 \\
(.08)\end{array}$ \\
\hline AGE & $\left(\begin{array}{l}.004^{*} \\
.16)\end{array}\right.$ & $\left(\begin{array}{l}.003^{\dagger} \\
.12\end{array}\right)$ & $\begin{array}{l}.002 \\
(.09)\end{array}$ & $\left(\begin{array}{l}.004^{* *} \\
.18)\end{array}\right.$ \\
\hline WOMEN & $\begin{array}{l}.04 \\
(.07)\end{array}$ & $\left(\begin{array}{l}-.01 \\
-.03)\end{array}\right.$ & $\left(\begin{array}{l}.14^{x \times x} \\
.22)\end{array}\right.$ & $\begin{array}{c}-.03 \\
(-.06)\end{array}$ \\
\hline MARRIEDc & $\begin{array}{l}.10 \\
(.16)\end{array}$ & $\begin{array}{l}.06 \\
(.10)\end{array}$ & $\begin{array}{l}.09^{x} \\
(.14)\end{array}$ & $\begin{array}{l}.09^{*} \\
(.15)\end{array}$ \\
\hline PARENTSd & $\left(\begin{array}{l}-.002 \\
(-.005)\end{array}\right.$ & $\left(\begin{array}{l}-.06 \\
-.11)\end{array}\right.$ & $\begin{array}{c}-.03 \\
(-.04)\end{array}$ & $\begin{array}{l}-.03 \\
(-.04)\end{array}$ \\
\hline $\begin{array}{l}\text { LEVEL OF } \\
\text { EDUCATION }\end{array}$ & $\left(\begin{array}{l}-.02^{*} \\
(-.20)\end{array}\right.$ & $\begin{array}{l}-.003 \\
(-.03)\end{array}$ & $\left(-.02^{* *}\right.$ & $\begin{array}{l}-.02^{\dagger} \\
(-.14)\end{array}$ \\
\hline $\begin{array}{l}\text { HOUSEHOLDe } \\
\text { INCOME }\end{array}$ & $\left(-.11^{\star}\right.$ & $\left(\begin{array}{l}-.09^{x} \\
-.14)\end{array}\right.$ & $\begin{array}{l}.03 \\
(.05)\end{array}$ & $\begin{array}{l}-.02 \\
-.04)\end{array}$ \\
\hline $\begin{array}{l}\text { OCCUPATION } \\
\text { (SOCIAL CLASS) }\end{array}$ & $\left(\begin{array}{l}.01^{*} \\
(.24)\end{array}\right.$ & $\begin{array}{l}-.002 \\
(-.07)\end{array}$ & $\begin{array}{l}-.003 \\
(-.06)\end{array}$ & $\begin{array}{l}-.001 \\
(-.11)\end{array}$ \\
\hline $\begin{array}{l}\text { LIVE NEAR } \\
\text { CO-WORKERS }\end{array}$ & $\begin{array}{l}-.008 \\
(-.06)\end{array}$ & $\begin{array}{c}-.001 \\
(-.007)\end{array}$ & $\begin{array}{l}.01 \\
(.07)\end{array}$ & $\left(\begin{array}{l}.04^{* *} \\
.23)\end{array}\right.$ \\
\hline $\begin{array}{l}\text { TIES TO CO- } \\
\text { WORKER FRIENDS }\end{array}$ & $\left(\begin{array}{l}-.01 \\
(-.08)\end{array}\right.$ & $\begin{array}{l}-.01 \\
(-.08)\end{array}$ & $\left(\begin{array}{l}-.03^{\mathrm{x}} \\
(-.20)\end{array}\right.$ & $\begin{array}{l}-.007 \\
(-.05)\end{array}$ \\
\hline CONST ANT & $.90^{* x}$ & $.47^{* \times *}$ & $.59^{\times \times x}$ & $.32^{*}$ \\
\hline $\mathrm{R}^{2}$ & .12 & .06 & .14 & .12 \\
\hline Adj. $R^{2}$ & .06 & .03 & .11 & .08 \\
\hline $\mathrm{N}$ & 152 & 258 & 261 & 244 \\
\hline 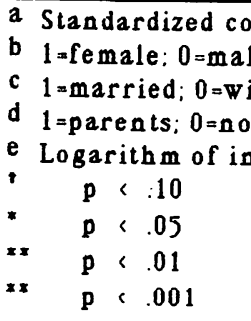 & $\begin{array}{l}\text { oefficients in p } \\
\text { le } \\
\text { idowed, divorce } \\
\text { onparents } \\
\text { ncome }\end{array}$ & $\begin{array}{l}\text { arentheses } \\
\text { d, never marri }\end{array}$ & & \\
\hline
\end{tabular}


Mid-American Review of Sociology

TABLE 5. RESULTS OF REGRESSION ANALYSS. 41 \& OVER BY REGIONa

\begin{tabular}{|c|c|c|c|c|}
\hline & $\begin{array}{c}\text { MODEL } \\
1 \\
\text { PACIFIC/MTN }\end{array}$ & $\begin{array}{c}\text { MODEL } \\
2 \\
\text { NO CENTRAL } \\
\end{array}$ & $\begin{array}{c}\text { MODEL } \\
3 \\
\text { SOUTH } \\
\end{array}$ & $\begin{array}{c}\text { MODEL } \\
4 \\
\text { EAST COAST } \\
\end{array}$ \\
\hline URBANISM & $\begin{array}{l}-.22^{\prime} \\
(-.25)\end{array}$ & $\begin{array}{l}-.09 \\
(-.07)\end{array}$ & $(.02)$ & $\left(\begin{array}{l}-.03 \\
(-.04)\end{array}\right.$ \\
\hline $\mathrm{AGE}$ & $\begin{array}{l}.0002 \\
(.005)\end{array}$ & $\begin{array}{l}.007 \\
(.18)\end{array}$ & $\begin{array}{l}.002 \\
(.05)\end{array}$ & $\begin{array}{l}.005 \\
(.13)\end{array}$ \\
\hline WOMEN' & $\left(\begin{array}{l}.02 \\
(.03)\end{array}\right.$ & $\begin{array}{l}-.15^{* *} \\
(-.25)\end{array}$ & $\begin{array}{l}.16^{* *} \\
(.23)\end{array}$ & $(-.05)$ \\
\hline MARRIEDc & $\left(\begin{array}{l}.22^{*} \\
(.33)\end{array}\right.$ & $\begin{array}{c}-.09 \\
(-.14)\end{array}$ & $\left(\begin{array}{l}.13^{*} \\
.17)\end{array}\right.$ & $\begin{array}{l}.03 \\
(.05)\end{array}$ \\
\hline PARENTSd & $\begin{array}{l}.013 \\
(.02)\end{array}$ & $(-.12)$ & $\begin{array}{l}-.03 \\
(-.04)\end{array}$ & $(-.07)$ \\
\hline $\begin{array}{l}\text { LEVEL OF } \\
\text { EDUCATION }\end{array}$ & $\left(\begin{array}{l}-.02 \\
-.20)\end{array}\right.$ & $\begin{array}{l}.02 \\
(.15)\end{array}$ & $\begin{array}{l}-.02^{*} \\
(-.20)\end{array}$ & $(-.02)$ \\
\hline $\begin{array}{l}\text { HOUSEHOLDe } \\
\text { INCOME }\end{array}$ & $\left(-.08^{* *}\right.$ & $\left(\begin{array}{l}-.01 \\
-.11)\end{array}\right.$ & $\begin{array}{c}.005 \\
(.04)\end{array}$ & $\begin{array}{l}-.003 \\
(-.03)\end{array}$ \\
\hline $\begin{array}{l}\text { OCCUPATION } \\
\text { (SOCIAL CLASS) }\end{array}$ & $\begin{array}{l}.02^{*} \\
(.52)\end{array}$ & $\begin{array}{l}-.008 \\
(-.21)\end{array}$ & $\begin{array}{l}-.001 \\
(-.05)\end{array}$ & $\begin{array}{l}.005 \\
(.10)\end{array}$ \\
\hline $\begin{array}{l}\text { LIVE NEAR } \\
\text { CO-WORKERS }\end{array}$ & $\begin{array}{l}.003 \\
(.02)\end{array}$ & $\begin{array}{l}-.04^{*} \\
(-.23)\end{array}$ & $\begin{array}{l}.025^{\dagger} \\
(.13)\end{array}$ & $\begin{array}{l}.05^{* *} \\
(.29)\end{array}$ \\
\hline $\begin{array}{l}\text { TIES TO CO- } \\
\text { WORKER FRIENDS }\end{array}$ & $\begin{array}{l}-.05^{*} \\
(-.33)\end{array}$ & $\begin{array}{c}-.03^{\dagger} \\
(-.17)\end{array}$ & $\begin{array}{l}-.04^{* *} \\
(-.20)\end{array}$ & $\left(-.03^{*}\right.$ \\
\hline CONSTANT & $.99^{\circ}$ & .34 & $.54^{*}$ & .43 \\
\hline$R^{2}$ & .35 & .27 & .17 & .14 \\
\hline$A d j . R^{2}$ & $\begin{array}{l}.18 \\
49\end{array}$ & $\begin{array}{r}.18 \\
92 \\
\end{array}$ & $\begin{array}{r}.10 \\
146 \\
\end{array}$ & $\begin{array}{l}.04 \\
96 \\
\end{array}$ \\
\hline
\end{tabular}

$\mathrm{N}$ atandardized coefficients in parentheses

b $1=$ female: $0=$ male

1

d l=parents; 0 =nonparents

e Logarithm of income

${ }^{t} p<.10$

* p<. 05
Close Relationships: Work and Family

close kinties for the South and the East Coast, while not living near co-workers related to close kinties in the North Central region.

Summarizing the truncated sample, the Pacific/Mountain region residents tended to have close kinties if they were married, had low household incomes but higher-class occupations, did not have close work-friends, and lived in less urban areas. Among residents of the North Central region close kinties were more likely for males, those not living near co-workers, and those without close work-friends. Among residents of the South region those having close kinties were likely to be female, married, have less education, live near co-workers, and not close friends with co-workers. Among residents of the East Coast region close kinties were more likely for those living near co-workers, although not having close work-friends.

\section{Differences Related to Urbanism.}

Results of the separate analyses by community type are presented in Table 6 . The model did not explain much of the variance for any community type, nor did it appear to be a good predictor for kinties. The rural community was the only type for which the workfriend-kintie trade-off occurred, and it was the only community type for which age was not a predictor of kinties. In rural areas, having many workers living nearby and having lower-class status also relate to close kinties. Interestingly, in the small towns, being parents was negatively related to having close kinties. In both the urban core and the metro/suburban areas, being married, having less education, and being older were all related to closer kinties.

Results of the analyses of workers ages 41 and older by community type are not shown. The model explained very little of the variance and was not a good predictor of kinties. However, the workfriend-kintie trade-off was significant for the metro area. A preliminary chi-square analysis of workfriends by kinties by community indicated that such a trade-off occurred only in the urban core. ${ }^{4}$ Conducted also by age-group, the trade-off occurred for only the 41-to-50 age-group, but in both the metro ${ }^{5}$ and urban ${ }^{6}$ areas.

\section{CONCLUSIONS}

The strong evidence of the existence of a trade-off between close personal relationships at work and close personal relationships with kin for middle-aged workers suggests that stage of the life cycle is an important determinant of feelings of closeness with 
Mid-American Review of Sociology

TABLE 6 RESULTS OF REGRESSION ANALYSES: PREDICTORS OF STRENGTH OF KINSHIP TIES AMONG WORKERS AGES 21 \& OVER BY COMMUNITY TYPEa

\begin{tabular}{|c|c|c|c|c|c|}
\hline & $\begin{array}{c}\text { MODEL } \\
1 \\
\text { RURAL } \\
\end{array}$ & $\begin{array}{c}\text { MODEL } \\
2 \\
\text { SEMIRURAL } \\
\end{array}$ & $\begin{array}{c}\text { MODEL } \\
3 \\
\text { TOWN } \\
\end{array}$ & $\begin{array}{c}\text { MODEL } \\
4 \\
\text { METRO } \\
\end{array}$ & $\begin{array}{c}\text { MODEL } \\
5 \\
\text { URBAN } \\
\end{array}$ \\
\hline$\overline{A G E}$ & $\begin{array}{l}.002 \\
(.08)\end{array}$ & $\begin{array}{l}.003^{*} \\
(.13)\end{array}$ & $\begin{array}{l}.003^{*} \\
(.13)\end{array}$ & $\left(\begin{array}{l}.002^{t} \\
.10)^{2}\end{array}\right.$ & $\left(\begin{array}{l}.003^{t} \\
(.12)\end{array}\right.$ \\
\hline WOMENb & $\left(\begin{array}{l}.05 \\
.09\end{array}\right)$ & $\begin{array}{l}.04 \\
(.07)\end{array}$ & $\begin{array}{l}.004 \\
(.01)\end{array}$ & $\left(\begin{array}{l}.02 \\
.03)\end{array}\right.$ & $\left(\begin{array}{l}.07 \\
.11)\end{array}\right.$ \\
\hline MARRIEDc & $\left(\begin{array}{l}.09 \\
.12\end{array}\right)$ & $\left(\begin{array}{l}.03 \\
.05\end{array}\right)$ & $\begin{array}{l}.08 \\
(.13)\end{array}$ & $\begin{array}{l}.08^{\dagger} \\
(.13)\end{array}$ & $\left(.11^{*}\right)$ \\
\hline PARENTSd & $\begin{array}{l}.09 \\
(.14)\end{array}$ & $\begin{array}{c}-.04 \\
(-.06)\end{array}$ & $\begin{array}{l}-.08^{1} \\
(-.14)\end{array}$ & $\left(\begin{array}{l}-.05 \\
(-.09)\end{array}\right.$ & $\left(\begin{array}{l}.02 \\
(.04)\end{array}\right.$ \\
\hline $\begin{array}{l}\text { LEVEL OF } \\
\text { EDUCATION }\end{array}$ & $\left(\begin{array}{l}.02 \\
.16\end{array}\right)$ & $\begin{array}{l}-.03^{* * *} \\
(-.27)\end{array}$ & $\left(\begin{array}{l}-.01 \\
-.10)\end{array}\right.$ & $\begin{array}{l}-.02^{*} \\
(-.17)\end{array}$ & $\begin{array}{l}-.02^{\dagger} \\
(-.15)\end{array}$ \\
\hline $\begin{array}{l}\text { HOUSEHOLD } \\
\text { INCOME }\end{array}$ & $\begin{array}{l}-.08 \\
(-.14)\end{array}$ & $\begin{array}{l}.004 \\
(.01)\end{array}$ & $\left(\begin{array}{l}-.06 \\
-.11)\end{array}\right.$ & $\begin{array}{l}-.06 \\
(-.11)\end{array}$ & $\left(\begin{array}{l}-.05 \\
(-.08)\end{array}\right.$ \\
\hline $\begin{array}{l}\text { OCCUPATION } \\
\text { (SOCIAL CLASS) }\end{array}$ & $\left(-.01^{*}\right)$ & $\begin{array}{l}-.001 \\
(-.01)\end{array}$ & $\begin{array}{c}-.0003 \\
(.01)\end{array}$ & $\begin{array}{l}-.0002 \\
(-.01)\end{array}$ & $\begin{array}{l}.002 \\
(.04)\end{array}$ \\
\hline $\begin{array}{l}\text { LIVE NEAR } \\
\text { CO-WORKERS }\end{array}$ & $\left(\begin{array}{l}.03^{1} \\
.17\end{array}\right)$ & $\left(\begin{array}{l}.03^{* *} \\
.16)\end{array}\right.$ & $\begin{array}{l}.02 \\
(.01)\end{array}$ & $\begin{array}{l}-.0002 \\
(-.001)\end{array}$ & $\begin{array}{l}.006 \\
(.03)\end{array}$ \\
\hline $\begin{array}{l}\text { TIES TO CO- } \\
\text { WORKER FRIENDS }\end{array}$ & 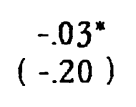 & $\left(\begin{array}{l}-.01 \\
(-.03)\end{array}\right.$ & $\left(\begin{array}{l}-.01 \\
-.10\end{array}\right)$ & $(-.01)$ & $\left(\begin{array}{c}-.01 \\
(-.09)\end{array}\right.$ \\
\hline CONST ANT & .23 & $.62^{*}$ & $.51^{* *}$ & $.65^{* * * *}$ & $.50^{* * *}$ \\
\hline$R^{2} \ldots \infty$ &. .16 & 12 & .06 & .08 & .10 \\
\hline Adj. $\mathrm{R}^{2}$ & .08 & .09 & .02 & .05 & .06 \\
\hline $\mathrm{N}$ & 108 & 228 & 202 & 275 & 229 \\
\hline 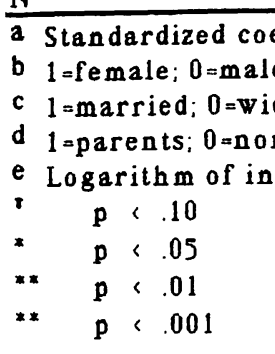 & $\begin{array}{l}\text { efficients } \\
\text { e } \\
\text { dowed, di } \\
\text { nparents } \\
\text { come }\end{array}$ & $\begin{array}{l}\text { in parenthes } \\
\text { vorced, never }\end{array}$ & married & & \\
\hline
\end{tabular}

Close Relationships: Work and Family

both kin and co-workers. However, as with most cross-sectional studies, life-cycle and cohort effects cannot be separated. Therefore, findings of differences between age-groups may reflect variations due to life-cycle stages and/or indicate other differences between age-cohorts tied neither to life-cycle stages nor to chronologial age. Nevertheless, there does seem to be some support for the workplace serving as a source of friendships which lessen the importance of kinship ties for some age-groups cross-regionally, specifically for middle-aged workers living in inner suburban and urban core communities. Yet, in some regions of the country close personal relationships with co-workers apparently become more important than close personal relationships with kin, regardless of age.

Results of this study also suggest that the prediction model based on Fischer's urban subculture theory may have some use in predicting close personal relationships with kin among working adults in the United States, although perhaps not in the way suggested by the theory. That is, contrary to urban subculture theory, feelings of personal closeness to kin may tend to increase as residence becomes more urban. To the extent this reflects maintained feelings of closeness to kin independent of amount of interaction with kin, such findings should assuage Fischer's concerns regarding urbanites' reactivation of dormant kinship ties.

Moreover, results of this study suggest that the factors predicting close ties with kin differ for different age-groups, and differ for different regions of the country. The influence of residential urbanism on having close personal relationships with kin may be limited to the Pacific/Mountain region of the country, and more specifically limited to workers over the age of 40 when the effects of workplace friendships are taken into account. Given the limitations imposed by the data set used in the analysis, the implications of these findings shoüld be regarded with caution, while suggesting further avenues of research into urban subculture theory models for predicting close personal relationships.

\section{FOOTNOTES}

1. Those with more education and high in cooperativeness had higher involvement with co-workers.

2. Wright, Erik Olin, principal investigator. Comparative Project on Class Structure and Class Consciousness: United States Survey, 1980. ICPSR ed. Madison, WI: University of Wisconsin, Institute for Research on Poverty (producer), 1986. Madison, WI: 
Mid-American Review of Sociology

Inter-university Consortium for Political and Social Research (distributor), 1986, Ann Arbor Michigan.

3. The West South Central region was omitted from analysis.

4. $\mathrm{X}^{2}(6)=14.42, \mathrm{p}<.03$, Pearson's $\mathrm{r}=-.10, \mathrm{p}<.05$

5. $\mathrm{X}^{2}(4)=11.0, \mathrm{p}<.03$, Pearson's $\mathrm{r}=-.36, \mathrm{p}<.006$

6. $\mathrm{X}^{2}(6)=20.94, \mathrm{p}<.002$, Pearson's $\mathrm{r}=-.40, \mathrm{p}<.009$

\section{REFERENCES}

Abrahamson, Mark and Valerie J. Carter

1986 "Tolerance, Urbanism and Region." American Sociological Review, 51:287-94.

Atchley, Robert

1972 Social Forces in Later Life. Belmont, CA: Wadsworth.

Bulmer, M.I.A.

1975 "Sociological Models of the Mining Community." Sociological Review, 23 (Feb):61-92.

Christenson, James A.

1983 "Urbanism and Community Sentiment: Extending Wirth's Model." Pp. 181-196 in Mark Baldassare (ed.), Cities and Urban Living. NY: Columbia University Press.

Derlega, Valerian J. and Barbara A. Winstead, (eds.)

1986 Friendship and Social Interaction. NY: Springer-Verlag.

Fehr, S. and Perlman, D.

1985 "The Family as a Social Network and Support System." Pp. 323-356 in. L. Labate (ed.), Handbook of Family Psychology and Therapy, Vol. 1. Homewood, IL: Dow Jones-Irwin.

Fischer, Claude S

1982 To Dwell Among Friends. Chicago: The University of Chicago Press.

1983 "Toward a Subcultural Theory of Urbanism." Pp. 84-114 in Mark Baldassare (ed.), Cities and Urban Living. NY: Columbia University Press.

\section{Kivett, Vira R.}

1985 "Aging in Rural Society: Non-Kin Community Relations and Participation." Pp. 171-192 in Raymond T. Coward and Gary R. Lee (eds.), The Elderly in Rural Society. NY: Springer Publishing Company.
Close Relationships: Work and Family

Lee, Gary R. and Margaret L. Cassidy

1985 "Family and Kin Relations of the Rural Elderly." Pp. 151-170 in Raymond T. Coward and Gary R. Lee (eds.), The Elderly in Rural Society. NY: Springer Publishing Company.

Lipset, S. M., M. Trow, and J. S. Coleman

1956 Union Democracy. NY: Free Press.

Litwak, E., and U. Szelenyi

1969 "Primary Group Structures and their Functions: Kin, Neighbor, and Friends." American Journal of Sociology,

Milardo, Robert M

1986 "Personal Choice and Social Constraint in Close Relationships: Applications of Network Analysis." 145-166 in Valerian J. Derlega and Barbara A. Winstead (eds.), Friendship and Social Interaction. NY: SpringerVerlag.

Matthews, Sarah H.

1986 Friendships Through the Life Course: Oral Biographies in Old Age. Beverly Hills, CA: Sage Publications Inc.

Pilcher, W. W.

1972 The Portland Longshoremen: A Dispersed Urban Community. NY: Holt, Rinehart and Winston.

Powers, E. A. and G. L. Bultena

1976 "Sex Differences in Intimate Friendships of Old Age." Journal of Marriage and the Family, 38:739-747.

Roberto, Karen A. and Jean Pearson Scott

1986 "Equity Considerations in the Friendships of Older Adults." Journal of Gerontology, 41:241-247.

Rosow, Irving

1967 Social Integration of the Aged. New York: Free Press.

Shulman, N.

1976 "Role Differentiation in Networks." Sociological Focus, 9:149-156.

Solano, Cecilia H.

1986 "People Without Friends: Loneliness and Its Alternatives." Pp. 227-246 in Valerian J. Derlega and Barbara A. Winstead (eds.), Friendship and Social Interaction. New York: Springer-Verlag.

United States Bureau of the Census.

1970 General Social and Economic Characteristics. Washington DC: Government Printing Office. 
Wellman, B.

1981 "The Community Question." American Journal of Sociology 84:1201-31.
SOME CONSIDERATIONS IN INTERVIEWING THE OLD, OLD

\author{
C. Ray Wingrove \\ University of Richmond
}

Mid-American Review of Sociology, 1987, Vol. XII, No. 2:71-76

Drawing upon personal experiences, the author makes a number of suggestions to follow when interviewing those in their late seventies and above. He deals with such topics as pitfalls in obtaining interviews, dress, rapport, length of interview, allaying respondents' fears, and coping with communication problems caused by interviewees' visual and hearing losses.

Some writers have pointed out recently that by emphasizing special characteristics and needs of the aged, gerontologists have unwittingly contributed to negative stereotypes and segregation of the old in this country (Kalish, 1979). With this in mind, I hesitate to single out a sub-category of the elderly as worthy of special consideration in the interview process. After all, should not the same general principles and guidelines of good interviewing be applied regardless of the age of the interviewee? The answer, of course, is "yes." But experiences over the years in interviewing subjects of all ages ranging from a nine year old fourth grader in rural Georgia to a 99 year old retired judge in Virginia, have sensitized me to the fact that there are some exceptional circumstances which cannot be ignored when dealing with certain age cohorts. I find this to be especially true when working with those whom professionals now refer to as the old, old or more specifically those 75 and over (Hendricks and Hendricks, 1986:40).

\section{OBTAINING THE INTERVIEW}

In spite of the prevalent assumption that older adults welcome interviews because they are bored, lonely, and have nothing to do, obtaining cooperation from subjects of any age for a lengthy interview is not easy. The researcher must convince the interviewee of the importance of the project and his or her part in it. Time must be found which does not infringe unduly upon busy schedules. Rapport must be established (see section on Rapport and Length of Interview) and confidentiality of responses guaranteed to the subject's satisfaction. However, an additional barrier surrounds the old, old, i.e., the one erected by those who protect 